\title{
Cytotoxic Assessment of Nile Tilapia (Oreochromis niloticus) from a Domestic Wastewater Canal with Heavy Metal Contamination
}

\author{
Manop Sriuttha ${ }^{1,2}$, Arthone Khammanichanh ${ }^{1,3}$, Isara Patawang ${ }^{1,4}$, \\ Alongklod Tanomtong ${ }^{1,5}$, Bundit Tengjaroenkul ${ }^{1,6}$ and Lamyai Neeratanaphan ${ }^{1,3 *}$ \\ ${ }^{1}$ Research Group on Toxic Substances in Livestock and Aquatic Animals, Khon Kaen University, Khon \\ Kaen, Muang 40002, Thailand \\ ${ }^{2}$ Faculty of Applied Science and Engineering, Khon Kaen University, Nong Khai Campus, \\ Nong Khai, Muang 43000, Thailand \\ ${ }^{3}$ Department of Environmental Science, Faculty of Science, Khon Kaen University, \\ Khon Kaen, Muang 40002, Thailand \\ ${ }^{4}$ Department of Biology, Faculty of Science, Chiang Mai University, Chiang Mai, Muang 50200, Thailand \\ ${ }^{5}$ Department of Biology, Faculty of Science, Khon Kaen University, Khon Kaen, Muang 40002, Thailand \\ ${ }^{6}$ Department of Veterinary Medicine, Faculty of Veterinary Medicine, Khon Kaen University, \\ Khon Kaen, Muang 40002, Thailand
}

Received December 1, 2015; accepted March 3, 2016

\begin{abstract}
Summary The study aimed to assess water quality parameters and heavy metal contamination in water, sediment and Nile tilapia (Oreochromis niloticus). Heavy metal concentrations in water were compared to Thailand's standard limits, and chromosomal aberrations in $O$. niloticus from contaminated water were compared with $O$. niloticus from an unaffected area. The samples were collected from a domestic wastewater canal, water quality parameters were assessed, and heavy metal concentrations $(\mathrm{Pb}, \mathrm{Cd}, \mathrm{Cr}, \mathrm{Cu}, \mathrm{Fe}, \mathrm{Mn}, \mathrm{Ni}$, and $\mathrm{Zn})$ in the water, sediment and fish were analyzed by inductively coupled plasma optical emission spectrometry (ICP-OES). The water quality parameters did not exceed standard values. The concentrations of heavy metals in the water and sediment did not exceed Thailand's standards, but the Ni concentration in the water was higher than the standard limits. Similarly, heavy metal concentrations in $O$. niloticus were also below the standard limits. Only the Cr concentration in $O$. niloticus tissues exceeded the standard limits. The diploid chromosome number of $O$. niloticus from both areas was $2 n=44$ and the chromosomal damage of $O$. niloticus in the affected area was higher than that in the unaffected area. There were six types of chromosomal aberrations: single chromatid break, single chromatid gap, centromeric gap, fragmentation, deletion and dicentric chromosomes. The most common chromosomal abnormality in the fish samples from the affected area was single chromatid gap, and the difference in chromosomal breakages in $O$. niloticus between the areas was significant $(p<0.05)$.
\end{abstract}

Key words Water quality, Heavy metals, Cytotoxic assessment, Oreochromis niloticus.

Pollution of the aquatic ecosystem is globally recognized as a potential threat to both humans and animal populations dependent on the aquatic environment (Biney et al. 1987). In Thailand, domestic wastewater is considered to be highly polluted and a serious environmental concern due to pollution by hazardous household waste and domestic non-treated discharges. Common pollutants include organic compounds, inorganic compounds, nitrogen, phosphorus and especially heavy metals such as arsenic (As), lead $(\mathrm{Pb})$, mercury $(\mathrm{Hg})$, cadmium $(\mathrm{Cd})$, chromium $(\mathrm{Cr})$, iron $(\mathrm{Fe})$, manganese (Mn), nickel (Ni) and zinc ( $\mathrm{Zn})$, according to Mara (2004). Heavy metals in aquatic systems are due to both natural sources and anthropogenic causes. Heavy met-

\footnotetext{
* Corresponding author, e-mail: hlamya@kku.ac.th

DOI: $10.1508 /$ cytologia. 82.41
}

als affect aquatic organisms and pose considerable environmental concerns (Amisah et al. 2009). They have been shown to accumulate in organisms, and some may become biomagnified in food chains (Singh et al. 2010). These pollutants are contaminants in wastewater, are harmful to human and aquatic animals and can damage the ecosystem. The Thailand Pollution Control Department (1995) reported that the main source of domestic wastewater $(80 \%)$ was discharge from households and other buildings at a rate of 291-306 L per person a day in 2012; this rate is estimated to rise to $318-322 \mathrm{~L}$ per person a day in 2017 in northeast Thailand. In Maha Sarakham city,the centrally located Somthawil Canal receives wastewater from the city to reduce the pollution in the water before drainage to the Chi River; however, the water is not treated (Maha Sarakham Administration Office 2012). Thus, the Somthawil Canal is considered 


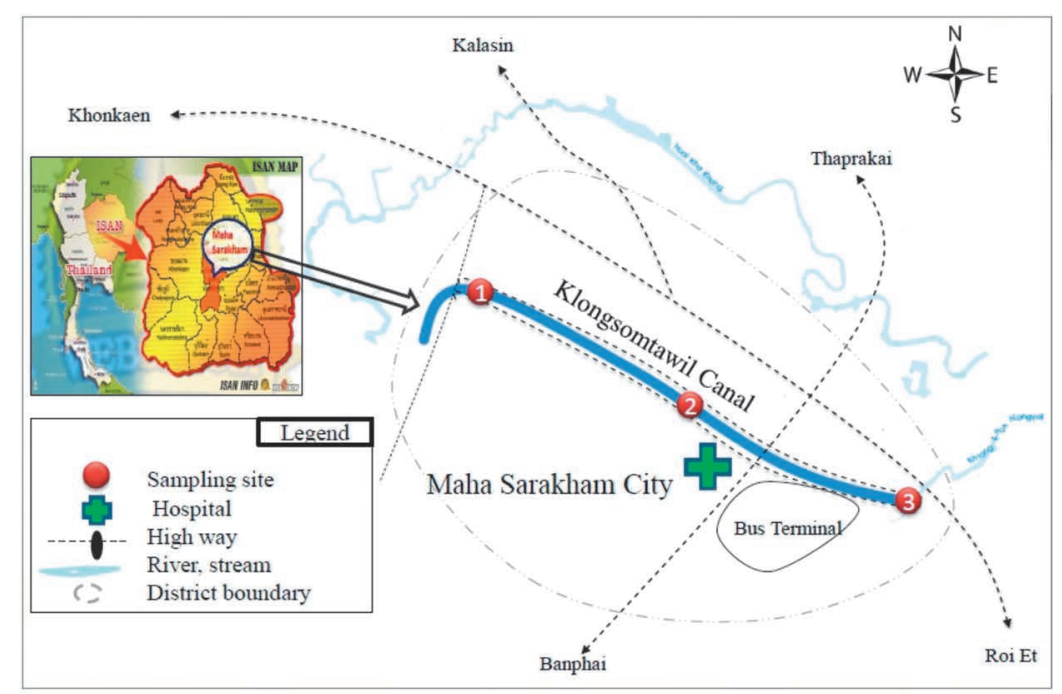

Fig. 1. Overview of the Somthawil Canal and locations of the three sites, labeled 1 through 3.

to be highly polluted because it receives wastewater from anthropogenic sources as well as rainfall, and the water is untreated. Nakinchar and Sattayarat (2002) reported that the concentrations of $\mathrm{Zn}, \mathrm{Pb}$ and $\mathrm{Cu}$ in sediments of the Somthawil and Kudnangyai Canals were highest in winter, with a range of $113.55-834.44 \mathrm{mg} \mathrm{kg}^{-1}$, $14.48-250.70 \mathrm{mg} \mathrm{kg}^{-1}$ and $12.96-267.41 \mathrm{mg} \mathrm{kg}^{-1}$, respectively. Priprem et al. (2007) studied heavy metals in freshwater fish along the Pong and Chi Rivers. Cd, Co, $\mathrm{Cr}, \mathrm{Cu}, \mathrm{Ni}, \mathrm{Pb}$ and $\mathrm{Zn}$ levels were determined in muscle and adipose tissues of fish. The results showed that the levels of heavy metal in the adipose tissue were higher than those found in the muscle tissue of fish in both rivers, but the levels did not exceed the standard limits.

Several studies have linked increases in cytogenetic abnormalities in fish and shellfish to polluted environments. Mohamed et al. (2008) measured the cytogenetic changes by observing the frequency of chromosomal aberrations in the gill cells of $O$. niloticus treated with copper sulfate and lead acetate, which revealed chromatid breaks, gaps, deletion, "stickiness" and fragmentation. Mahrous and Abdou (2001) determined that environmental water pollution (agricultural or industrial wastewater) has significant effects on $O$. niloticus and Clarias lazera, observing chromosome breaks, deletion and centromeric attenuation in somatic cells. Parveen and Shadab (2012) studied C. punctatus exposed to cadmium chloride for three days. The results showed that $C$. punctatus exposed to $5.0 \mathrm{mg} \mathrm{L}^{-1}$ have chromosomal abnormalities such as chromosomal breaks, gaps, translocations and dicentric and ring chromosomes. One study showed that $\mathrm{Cd}$ produced genotoxic effects in fish. Nile tilapia is one of the most widely farmed freshwater fish (Martins et al. 2004) and is a key species in aquatic ecosystems as a community food source and an economically important fish species. Various species of Nile tilapia have been favored by many earlier researchers as test models for both cytogenetic and molecular studies
(Martins et al. 2000, 2002). Therefore, this study was carried out to assess the heavy metal contamination and investigate the chromosomal aberrations of Nile tilapia affected by domestic wastewater compared with fish from a non-polluted reference area as well as to provide insight into environmental management in the future.

Materials and methods

\section{Sampling sites}

Sampling was conducted in the Muang District of Maha Sarakham Province, Thailand (Fig. 1). The water, sediment, and fish samples were collected from three sampling sites at Somthawil Canal during the winter season and compared to samples from a non-polluted reference area, the reservoir in the Khon Kaen Province, which has no domestic wastewater contamination.

\section{Water sample}

Water was tested for temperature, $\mathrm{pH}$, dissolved oxygen (DO) and biological oxygen demand (BOD). Duplicate water samples were taken with a water sampler from three locations, sites 1, 2 and 3, between 09:0011:00 a.m. at a depth of $30 \mathrm{~cm}$ below the water surface with sulfuric acid and stored at $4{ }^{\circ} \mathrm{C}$ in clean $1000-\mathrm{mL}$ plastic sampling bottles according to APHA (2005).

\section{Sediment sample}

Duplicates of three sediment samples (sites 1,2 and 3) up to $20 \mathrm{~cm}$ in length were taken from the sites using a grab sampler as described in Boyd and Tucker (1992), then transferred to the laboratory and left to dry at room temperature.

\section{Fish sample}

Six $O$. niloticus specimens were collected from the domestic wastewater canal and the reference site. The wet weight and total body length of the fish were mea- 
sured. Then, kidney cell preparations were performed, and the fish were frozen for further investigation.

\section{Analysis of heavy metals in water, sediment and fish samples}

A total of $2.5 \mathrm{~g}$ of each sample was predigested with $3 \mathrm{~mL}$ of concentrated nitric acid overnight at $40^{\circ} \mathrm{C}$. After cooling the samples, $2 \mathrm{~mL}$ of $30 \%$ hydrogen peroxide was added. The container was covered, placed in a highpressure stainless steel bomb and incubated in an oven at $160^{\circ} \mathrm{C}$ for $4 \mathrm{~h}$. After cooling the samples, the solution was diluted with Milli-Q water, and $50 \mathrm{~g}$ was transferred into a PET bottle. The heavy metal concentrations in each sample were determined using induction coupled plasma-optical emission spectrometry (ICP-OES; Optima 8300) (Chand and Prasad 2013). The ICP-OES measurements for $\mathrm{Pb}, \mathrm{Cd}, \mathrm{Cr}, \mathrm{Cu}, \mathrm{Fe}, \mathrm{Mn}, \mathrm{Ni}$, and $\mathrm{Zn}$ were taken at 220.353, 226.502, 267.716, 324.752, 259.939, $259.372,231.604$, and $213.857 \mathrm{~nm}$, respectively. The accuracy of the heavy metal results was evaluated with certified reference material (CRM) via the 3111C method (APHA 2005). Two aliquots of the CRM were spiked with a known amount of heavy metal standard. One spike was analyzed according to the $3111 \mathrm{C}$ method, and the other was analyzed with the $3111 \mathrm{~B}$ method (APHA 2005). The heavy metal recoveries were in the 96-100\% range, which was determined to be acceptable (USEPA 1994).

\section{Chromosome preparation and assessment}

Chromosomal preparations from kidney cells were obtained based on the techniques by Chen and Ebeling (1968) and Nanda et al. (1995) with some modifications. The fish samples were transferred to the laboratory, $0.2 \%$ phytohemagglutinin (PHA) solution was injected into the fish abdominal cavity, and then $0.05 \%$ colchicine solution was injected into the fish abdominal cavity ( $1 \mathrm{~mL}$ per $100 \mathrm{~g}$ body weight) after $24 \mathrm{~h}$. The treated samples were left for $1-2 \mathrm{~h}$ before incubation on ice. Fish kidneys were removed and cut into small pieces before being mixed with $0.075 \mathrm{M} \mathrm{KCl}$, and large pieces were discarded. The $8-\mathrm{mL}$ cell pellet was transferred to a $15-\mathrm{mL}$ centrifuge tube and incubated for $25-35 \mathrm{~min}$ at room temperature. $\mathrm{KCl}$ was discarded following supernatant centrifugation at $1200-1500 \mathrm{rpm}$ for $10 \mathrm{~min}$, and cells were fixed in cold, freshly made fixative solution (3 methanol: 1 acetic acid) to stop $\mathrm{KCl}$. The fixative was gradually added up to $8-\mathrm{mL}$ before centrifuging again at $1200-1500 \mathrm{rpm}$ for $10 \mathrm{~min}$, and the supernatant was discarded. The fixation process was repeated three to four times until the supernatant was clear, and the pellet was mixed with $1 \mathrm{~mL}$ fixative. The mixture was spotted onto a clean slide by a micropipette followed by air drying (Kasiroek et al. 2017).

Conventional staining was carried out using $20 \%$ Giemsa's solution for $30 \mathrm{~min}$ (Rooney 2001, Chooseang- jaew et al. 2017). Ag-NOR banding was performed by adding four drops of $50 \%$ silver nitrate and $2 \%$ gelatin on slides, respectively. The slides were sealed with cover glasses and incubated at $60^{\circ} \mathrm{C}$ for $5 \mathrm{~min}$. Then, the slides were soaked in distilled water until the cover glasses separated (Howell and Black 1980, Sangpakdee et al. 2017).

Chromosome counting and the recording of abnormal chromosomes were performed on mitotic metaphase cells under a light microscope. Three hundred clearly observable and well-spread chromosome plates were selected and photographed. The fundamental number (NF, number of chromosome arms) was obtained by assigning a value of two to metacentric, submetacentric and acrocentric chromosomes and one to a telocentric chromosome. All parameters were used in karyotyping (Chooseangjaew et al. 2017). The cytotoxicity was evaluated from chromosomal aberrations by determining the percentage of chromosome breakages per 100 metaphase cells per individual sample with a light microscope.

\section{Statistical analysis}

Heavy metal concentrations in the environment, including $O$. niloticus samples from the domestic wastewater canal, and the percentage of chromosomal abnormalities in $O$. niloticus from the domestic wastewater canal and reference site were analyzed using a $t$-test. All of the statistical tests were conducted at a $95 \%$ confidence level.

\section{Results and discussion}

\section{Water quality}

Water quality parameters (temp, $\mathrm{pH}, \mathrm{DO}$ and BOD) in the domestic wastewater canal are shown in Table 1 . The temperature range was $30.46-32.40^{\circ} \mathrm{C}$, the $\mathrm{pH}$ range was 7.28-10.56, DO values were 7.36-8.76 $\mathrm{mg} \mathrm{L}^{-1}$ and BOD was $7.00-8.03 \mathrm{mg} \mathrm{L}^{-1}$ in the study site. The results indicated that the water quality parameters did not exceed standard values, and DO and BOD values are acceptable for aquatic life. The $\mathrm{pH}$ of site 2 exceeded the standard defined by the Thailand Pollution Control Department (2001), but the average $\mathrm{pH}$ did not exceed the Thailand standard. Alabaster and Lloyd (1980) identified the $\mathrm{pH}$ range that is not directly lethal to freshwater fish as 5.0-9.0. pH; values between 6.5 and 9.0 are satisfactory on a long-term basis for fish and other freshwater aquatic life. Inland freshwater with fish generally has $\mathrm{pH}$ values ranging from approximately 6.0 to 9.0 (Ellis 1937), with most water, particularly those with healthy, diverse, and productive fish and macroinvertebrates communities, having a $\mathrm{pH}$ between approximately 6.5 and 8.5 . While some organisms can tolerate environments with higher or lower $\mathrm{pH}$ values, they are rare, and their extreme tolerances are not reflective of the $\mathrm{pH}$ tolerated by the majority of organisms occurring in a given aquatic eco- 
Table 1. Water quality parameters (temperature, $\mathrm{pH}, \mathrm{DO}$ and BOD) of the domestic wastewater canal.

\begin{tabular}{|c|c|c|c|c|}
\hline \multirow{2}{*}{$\begin{array}{c}\text { Domestic } \\
\text { wastewater canal }\end{array}$} & \multicolumn{4}{|c|}{ Parameters } \\
\hline & Temperature $\left({ }^{\circ} \mathrm{C}\right)$ & $\mathrm{pH}$ & $\mathrm{DO}\left(\mathrm{mg} \mathrm{L}^{-1}\right)$ & $\mathrm{BOD}\left(\mathrm{mg} \mathrm{L}^{-1}\right)$ \\
\hline Site 1 & 30.46 & 8.56 & 8.56 & 8.03 \\
\hline Site 2 & 32.40 & 10.56 & 7.36 & 7.00 \\
\hline Site 3 & 32.10 & 7.28 & 8.76 & 7.93 \\
\hline Mean \pm SD & $31.65 \pm 1.04$ & $8.80 \pm 1.65$ & $8.23 \pm 0.76$ & $7.65 \pm 0.57$ \\
\hline Standard & - & 5-9 & 4.00 & 20 \\
\hline
\end{tabular}

Remarks: Thailand's wastewater quality standards (Thailand Pollution Control Department 2001)

Table 2. Heavy metal concentrations in the water of the domestic wastewater canal.

\begin{tabular}{|c|c|c|c|c|c|c|c|c|}
\hline $\begin{array}{c}\text { Domestic } \\
\text { wastewater canal }\end{array}$ & $\mathrm{Pb}\left(\mathrm{mgL}^{-1}\right)$ & $\mathrm{Cd}\left(\mathrm{mg} \mathrm{L}^{-1}\right)$ & $\mathrm{Cr}\left(\mathrm{mgL}^{-1}\right)$ & $\mathrm{Cu}\left(\mathrm{mgL}^{-1}\right)$ & $\mathrm{Fe}\left(\mathrm{mgL}^{-1}\right)$ & $\operatorname{Mn}\left(\mathrm{mg} \mathrm{L}^{-1}\right)$ & $\mathrm{Ni}\left(\mathrm{mgL}^{-1}\right)$ & $\mathrm{Zn}\left(\mathrm{mg} \mathrm{L}^{-1}\right)$ \\
\hline Site 1 & 0.04 & 0.003 & 0.003 & 0.002 & 0.95 & 0.21 & 0.002 & 0.13 \\
\hline Site 2 & ND & 0.003 & 0.003 & ND & 0.70 & 0.67 & ND & 0.05 \\
\hline Site 3 & 0.02 & 0.003 & 0.003 & 0.104 & 0.90 & 0.78 & 0.179 & 0.14 \\
\hline Mean \pm SD & $0.03 \pm 0.02$ & $0.003 \pm 0.0003$ & $0.003 \pm 0.0003$ & $0.053 \pm 0.072$ & $0.85 \pm 0.13$ & $0.55 \pm 0.30$ & $0.90 \pm 0.125$ & $0.11 \pm 0.05$ \\
\hline Standard & 0.05 & 0.05 & 0.25 & 0.1 & - & 1.00 & 0.1 & 1.00 \\
\hline
\end{tabular}

Remarks: Thailand's surface water quality standards (Thailand Pollution Control Department 1994), ND=Not detected

Table 3. Heavy metal concentrations in the sediment of the domestic wastewater canal.

\begin{tabular}{|c|c|c|c|c|c|c|c|c|}
\hline $\begin{array}{c}\text { Domestic } \\
\text { wastewater canal }\end{array}$ & $\mathrm{Pb}\left(\mathrm{mg} \mathrm{kg}^{-1}\right)$ & $\mathrm{Cd}\left(\mathrm{mg} \mathrm{kg}^{-1}\right)$ & $\mathrm{Cr}\left(\mathrm{mg} \mathrm{kg}^{-1}\right)$ & $\mathrm{Cu}\left(\mathrm{mg} \mathrm{kg}^{-1}\right)$ & $\mathrm{Fe}\left(\mathrm{mg} \mathrm{kg}^{-1}\right)$ & $\operatorname{Mn}\left(\mathrm{mgkg}^{-1}\right)$ & $\mathrm{Ni}\left(\mathrm{mg} \mathrm{kg}^{-1}\right)$ & $\mathrm{Zn}\left(\mathrm{mgkg}^{-1}\right)$ \\
\hline Site 1 & 6.58 & 0.49 & 10.77 & 4.31 & 5958.05 & 178.57 & 3.86 & 22.89 \\
\hline Site 2 & 7.21 & 0.47 & 13.11 & 12.56 & 5486.02 & 174.33 & 3.94 & 33.60 \\
\hline Site 3 & 6.02 & 0.37 & 9.27 & 2.75 & 4079.75 & 182.36 & 2.53 & 41.43 \\
\hline Mean \pm SD & $6.60 \pm 0.60$ & $0.44 \pm 0.07$ & $11.05 \pm 1.93$ & $6.54 \pm 5.27$ & $5174.61 \pm 977.11$ & $178.42 \pm 4.02$ & $3.44 \pm 0.79$ & $32.64 \pm 9.31$ \\
\hline Standard & 400 & 37 & 300 & - & - & 1800 & 1600 & - \\
\hline
\end{tabular}

Remarks: Thailand's soil quality standards for habitat and agriculture (Thailand Pollution Control Department 2004)

system.

Heavy metal concentrations in the water from the domestic wastewater canal

Heavy metal concentrations $(\mathrm{Pb}, \mathrm{Cd}, \mathrm{Cr}, \mathrm{Cu}, \mathrm{Fe}, \mathrm{Mn}$, $\mathrm{Ni}$ and $\mathrm{Zn}$ ) in the water are shown in Table 2. Heavy metal concentrations in the water were found to have the following ranges: $\mathrm{Pb}$, not detected to $0.04 ; \mathrm{Cu}$, not detected to $0.104 ; \mathrm{Fe}, 0.70-0.95 ; \mathrm{Mn}, 0.21-0.78$; Ni, not detected to 0.179 and $\mathrm{Zn}, 0.05-0.14 \mathrm{mg} \mathrm{L}^{-1}$. Cd and $\mathrm{Cr}$ concentrations were $0.003 \mathrm{mgL}^{-1}$. These ranges and the average concentrations of $\mathrm{Pb}, \mathrm{Cd}, \mathrm{Cr}, \mathrm{Cu}, \mathrm{Fe}, \mathrm{Mn}$ and $\mathrm{Zn}$ did not exceed Thailand's surface water quality standards (Thailand Pollution Control Department 1994). However, the Ni concentration at site 3 and the average concentration exceeded the standard. $\mathrm{Ni}$ is one of the most common metals in surface water (USEPA 1986). Ni enters surface water naturally from smelting, refining, alloy processing, scrap metal reprocessing, fossil fuel combustion, and waste incineration (NAS 1975, WHO 1991). Ni poisoning symptoms in fish include surfacing, rapid mouth movements, opercula movements, and, prior to death, convulsions and loss of equilibrium (Khangarot and Ray 1990). Other symptoms include decreased concentrations of glycogen in muscle and liver with simultaneous increases in levels of lactic acid and glucose in the blood (Ghazaly 1992). Heavy metals may not highly accumulate in the surface water of the canal because they settle into the sediment.

\section{Heavy metal concentrations in the sediment}

Heavy metal concentrations in the sediment $(\mathrm{Pb}, \mathrm{Cd}$, $\mathrm{Cr}, \mathrm{Cu}, \mathrm{Fe}, \mathrm{Mn}, \mathrm{Ni}$ and $\mathrm{Zn}$ ) are shown in Table 3. Heavy metal ranges in the sediment were as follows: $\mathrm{Pb}, 6.02-$ 7.21; Cd, 0.37-0.49; Cr, 9.27-13.11; Cu, 2.75-12.56; Fe, 4079.75-5958.05; Mn, 174.33-182.36; Ni, 2.53-3.94 and $\mathrm{Zn}, 22.89-41.43 \mathrm{mg} \mathrm{kg}^{-1}$. The concentrations of $\mathrm{Pb}$, $\mathrm{Cd}, \mathrm{Cr}, \mathrm{Mn}$ and Ni did not exceed Thailand's soil quality standards for habitat and agriculture (Thailand Pollution Control Department 2004), and $\mathrm{Cu}, \mathrm{Fe}$ and $\mathrm{Zn}$ have no standard limits. However, they were higher than those recorded in the water samples. This is because sediments act as reservoir for all contaminants and organic matter deposited by humans and the ecosystem.

Heavy metal concentrations in Oreochromis niloticus from the domestic wastewater canal and reference site

Heavy metal concentrations in the O. niloticus tis- 
Table 4. Heavy metal concentrations in Oreochromis niloticus of the domestic wastewater canal and reference site (wet weight).

\begin{tabular}{|c|c|c|c|c|c|c|c|c|c|}
\hline Area & Samples & $\mathrm{Pb}\left(\mathrm{mg} \mathrm{kg}^{-1}\right)$ & $\mathrm{Cd}\left(\mathrm{mg} \mathrm{kg}^{-1}\right)$ & $\mathrm{Cr}\left(\mathrm{mg} \mathrm{kg}^{-1}\right)$ & $\mathrm{Cu}\left(\mathrm{mg} \mathrm{kg}^{-1}\right)$ & $\mathrm{Fe}\left(\mathrm{mg} \mathrm{kg}^{-1}\right)$ & $\operatorname{Mn}\left(\mathrm{mgkg}^{-1}\right)$ & $\mathrm{Ni}\left(\mathrm{mg} \mathrm{kg}^{-1}\right)$ & $\mathrm{Zn}\left(\mathrm{mg} \mathrm{kg}^{-1}\right)$ \\
\hline \multirow{4}{*}{$\begin{array}{l}\text { Domestic } \\
\text { wastewater canal }\end{array}$} & Sample 1 & 0.12 & 0.01 & 2.46 & 0.39 & 32.88 & 1.55 & 0.06 & 17.25 \\
\hline & Sample 2 & 0.33 & 0.02 & 2.25 & 0.49 & 67.04 & 15.16 & 0.44 & 20.50 \\
\hline & Sample 3 & 0.21 & 0.04 & 4.50 & 0.66 & 40.78 & 29.82 & 0.29 & 26.40 \\
\hline & Mean \pm SD & $0.22 \pm 0.10$ & $0.02 \pm 0.02$ & $3.07 \pm 1.24$ & $0.51 \pm 0.14$ & $46.90 \pm 17.88$ & $15.51 \pm 14.14$ & $0.27 \pm 0.19$ & $21.38 \pm 4.64$ \\
\hline \multirow[t]{4}{*}{ Reference site } & Sample 1 & 0.50 & 0.02 & 1.92 & 0.92 & 20.72 & 2.96 & 0.72 & 22.21 \\
\hline & Sample 2 & 0.43 & 0.10 & 1.87 & 1.40 & 41.50 & 6.28 & 0.76 & 36.91 \\
\hline & Sample 3 & 0.27 & 0.03 & 1.92 & 0.93 & 45.29 & 4.37 & 0.76 & 23.08 \\
\hline & Mean \pm SD & $0.40 \pm 0.12$ & $0.05 \pm 0.05$ & $1.90 \pm 0.03$ & $1.08 \pm 0.27$ & $35.84 \pm 13.23$ & $4.54 \pm 1.66$ & $0.75 \pm 0.02$ & $27.40 \pm 8.25$ \\
\hline$P$-value & & $0.11^{\mathrm{ns}}$ & $0.37^{\mathrm{ns}}$ & $0.17^{\mathrm{ns}}$ & $0.03^{\mathrm{a}}$ & $0.43^{\mathrm{ns}}$ & $0.25^{\mathrm{ns}}$ & $0.01^{\mathrm{a}}$ & $0.33^{\mathrm{ns}}$ \\
\hline Standard & & 0.5 & 0.1 & 2.0 & 20 & - & - & - & 100 \\
\hline
\end{tabular}

Remarks: Thailand's food quality standards (Thailand Pollution Control Department 1986), a=significant, ns=not significant.

sue samples $(\mathrm{Pb}, \mathrm{Cd}, \mathrm{Cr}, \mathrm{Cu}, \mathrm{Fe}, \mathrm{Mn}, \mathrm{Ni}$ and $\mathrm{Zn})$ are shown in Table 4. The wet weight and total length of $O$. niloticus were $54-102 \mathrm{~g}$ and $14-19 \mathrm{~cm}$, respectively. The concentrations of heavy metals in fish tissue are closely associated with the metal concentrations of water and sediment from the domestic wastewater canal. The range of the concentrations are: $\mathrm{Pb}, 0.12-0.33$; $\mathrm{Cd}, 0.01-0.04$; $\mathrm{Cr}, 2.25-4.50 ; \mathrm{Cu}, 0.39-0.66 ; \mathrm{Fe}, 32.88-67.04 ; \mathrm{Mn}$, $1.55-29.82$; Ni, $0.06-0.44$ and $\mathrm{Zn}, 17.25-26.40 \mathrm{mg} \mathrm{kg}^{-1}$ wet weight in the domestic wastewater canal and $\mathrm{Pb}$, 0.27-0.50; Cd, 0.02-0.1; Cr, 1.87-1.92; Cu, 0.92-1.40; Fe, 20.72-45.29; Mn, 2.96-6.28; Ni, 0.72-0.76 and Zn, $22.21-36.91 \mathrm{mg} \mathrm{kg}^{-1}$ wet weight in the reference area. These data revealed that concentrations of heavy metals in $O$. niloticus in both areas were low and that $\mathrm{Pb}, \mathrm{Cd}$, $\mathrm{Cu}$ and $\mathrm{Zn}$ levels did not exceed Thailand's food quality standards, while Fe, Mn and Ni have no standards. There were significant differences in $\mathrm{Cu}$ and $\mathrm{Ni}$ concentrations in the $O$. niloticus from the domestic wastewater canal and reference area, while the other heavy metal concentrations were not significantly different between the fish from the two areas.

$\mathrm{Cr}$ concentrations were higher than those of the other metals in $O$. niloticus and exceeded standard limits, but other metal concentrations were lower than the standard limits. This may be due to human activities and the effects of rain, for example, stainless steel and dye or pigments coming into contact with running water, causing $\mathrm{Cr}$ to leach into the reservoir. Subsequently, $\mathrm{Cr}$ in wastewater will not silt or condense into the sediment. Thus, it can move with the water flow, which likely caused contamination in the water source. Higher levels of $\mathrm{Cr}$ in water caused more $\mathrm{Cr}$ accumulation in Nile tilapia compared to other metals. Although the other heavy metal concentrations did not exceed standards, essential heavy metals also become toxic when their concentrations exceed those required for correct nutrition. According to Otchere (2003), metal toxicity occurs when an organism is unable to cope with additional metal concentrations by direct usage, storage and excretion. The results obtained from the laboratory analysis indicate that $O$. niloticus from the domestic wastewater canal is contaminated with heavy metals. There are other possible environmental measures of toxicity in addition to the heavy metal concentrations found in this field study (Ansari et al. 2004). Heavy metals are well-known environmental pollutants that cause serious health hazards to humans, but their effects are not immediate and can appear after many years (Liu et al. 2007). Heavy metal release into the aquatic environment can damage both aquatic species diversity and ecosystems due to their toxicity and accumulative behavior (Edwards et al. 2001, Smith and Windom 1972). $\mathrm{Pb}, \mathrm{Cd}, \mathrm{Cr}, \mathrm{Cu}, \mathrm{Fe}, \mathrm{Mn}, \mathrm{Ni}$ and $\mathrm{Zn}$ are usually found in wastewater, and these metals are toxic to aquatic life at low concentrations, particularly in fish, and may affect the food chain and the ecosystem (Ellis 1996). Therefore, Nile tilapia caught from the domestic wastewater canal may pose health hazards for consumers.

\section{Assessment of chromosomal aberrations}

This study revealed that heavy metal concentrations in $O$. niloticus samples from both areas are correlated with chromosomal aberrations. The diploid number of chromosomes in $O$. niloticus from the domestic wastewater canal and reference site was $2 n=44$. Most chromosomes were rod-shaped, with one pair of long acrocentric 'marker' chromosomes that could be distinguished from others in the complement. This is in accordance with previous studies (Arai and Koike 1980, Vervoort 1980, Chen and Chen 1983, Majumdar and McAndrew 1986, Crosetti et al. 1998, Sofy et al. 2008), which showed that the diploid number of $O$. niloticus was $2 n=44$. The karyotype of $O$. niloticus from both areas was composed of 2 submetacentric, 12 acrocentric and 30 telocentric chromosomes (Fig. 2). This is inconsistent with the report of Sofy et al. (2008), which demonstrated that $O$. niloticus has 2 submetacentric, 24 subtelocentric and 18 telocentric chromosomes. The karyotype of O. niloticus from the study site showed chromosomal 

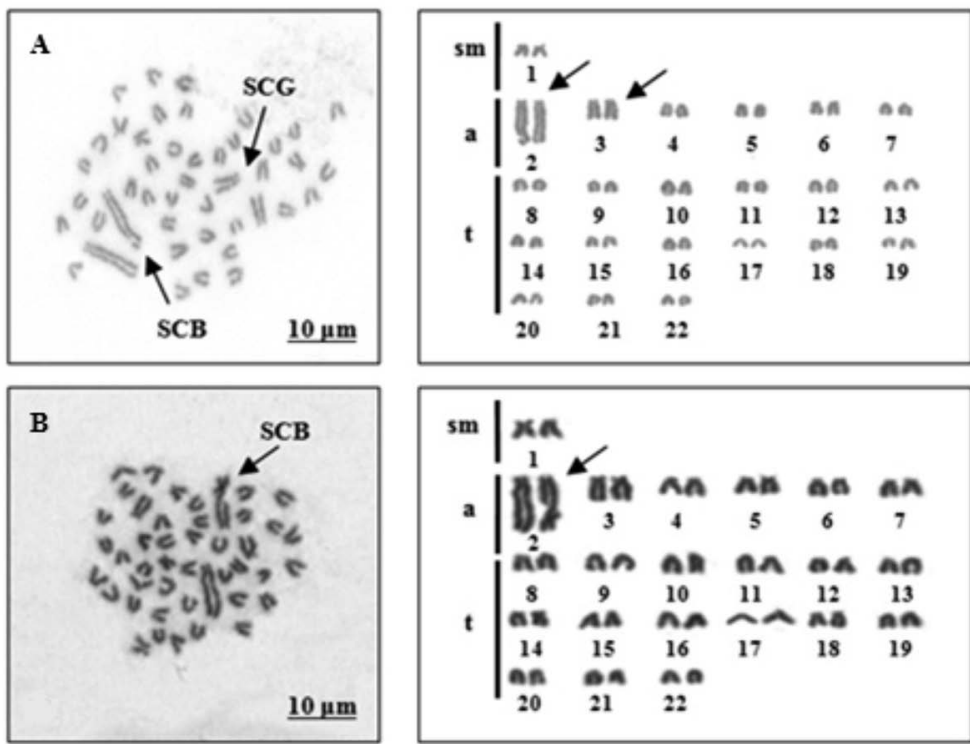

Fig. 2. Conventional staining of the metaphase chromosome plates and karyotypes of individual (A, B) O. niloticus $(2 n=44)$ samples from the domestic wastewater canal. Arrows indicate chromosomal aberrations.
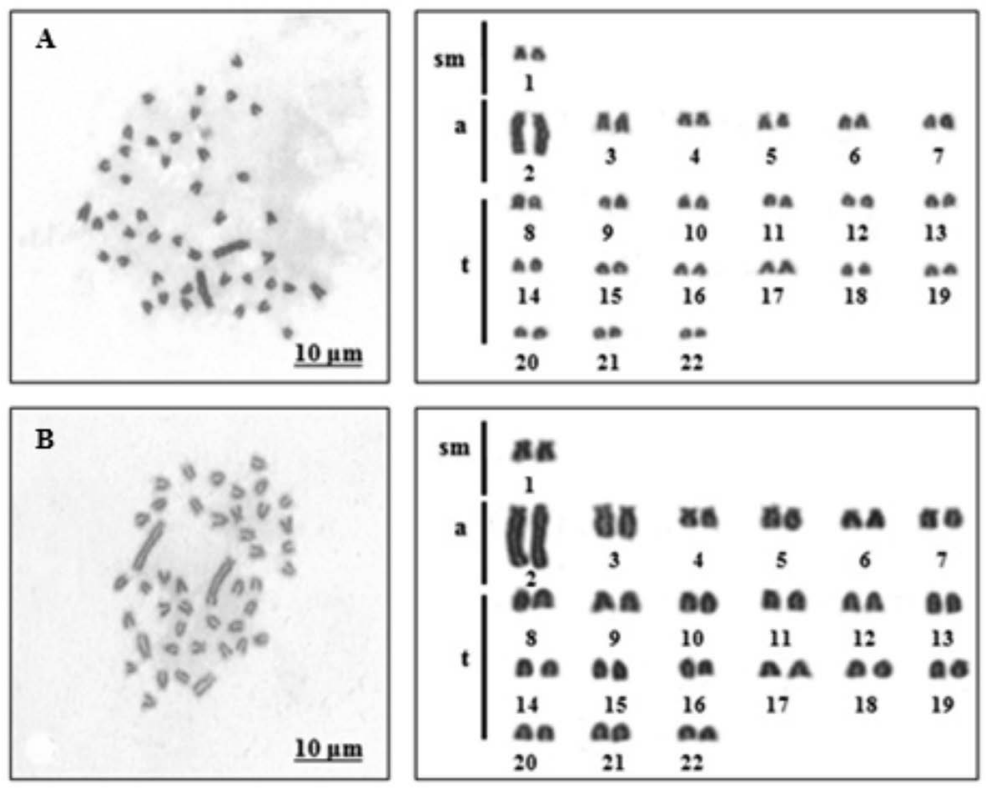

Fig. 3. Conventional staining of the metaphase chromosome plates and karyotypes of individual (A, B) O. niloticus (2n=44) samples from the reference site.

aberrations, and O. niloticus from both areas displayed terminal Ag-NOR on chromosome pair 1 (Fig. 4). The $2 n$ of the mitotic metaphase cells and karyotypes of $O$. niloticus, conventionally stained with Ag-NOR, did not differ between the sample areas. Staining with Ag-NOR did not detect the chromosomal aberrations of $O$. niloticus, while conventional staining techniques could detect chromosomal aberrations. The different types of abnormalities in the metaphase-spread cells of $O$. niloticus samples from the domestic wastewater canal are shown in Fig. 5. The different categories of chromosomal aberrations were single chromatid gap (SCG), single chromatid break (SCB), centromere gap (CG), fragmentation
(F), deletion (D) and dicentric chromosome (DC). The most common chromosomal aberration in the samples from the study site was SCG. The number and percentage of chromosomal aberrations of $O$. niloticus samples from the domestic wastewater canal and reference site are shown in Table 5. The number of types of chromosomal aberrations of the $O$. niloticus are as follows: SCG, SCB, CG, F, D and DC were 20, 66, 20, 6, 5 and 40 aberrations from the domestic wastewater canal and $1,8,4,2,0$ and 2 aberrations from the reference site, respectively. One hundred clearly observable slides were used for this study, and the total number of chromosomal anomalies found in the $O$. niloticus samples from the do- 

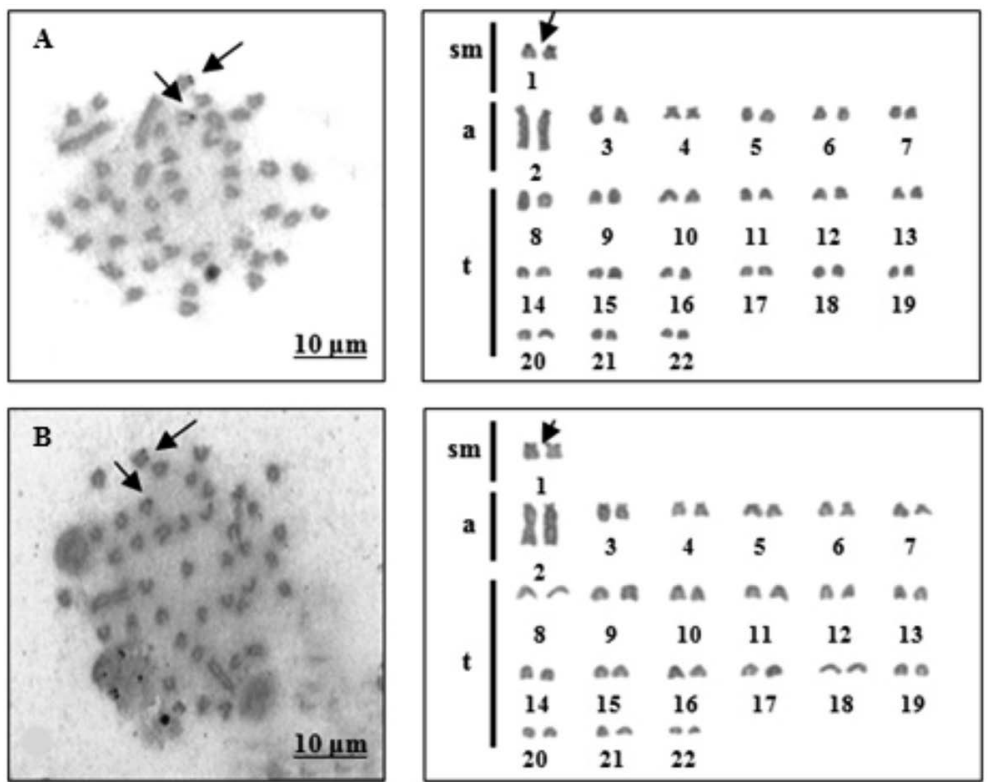

Fig. 4. Ag-NOR banding of metaphase chromosome plates and karyotypes of $O$. niloticus $(2 n=44)$ from the reference site (A) and domestic wastewater canal (B). Arrows indicate NOR-bearing chromosome pair 1.
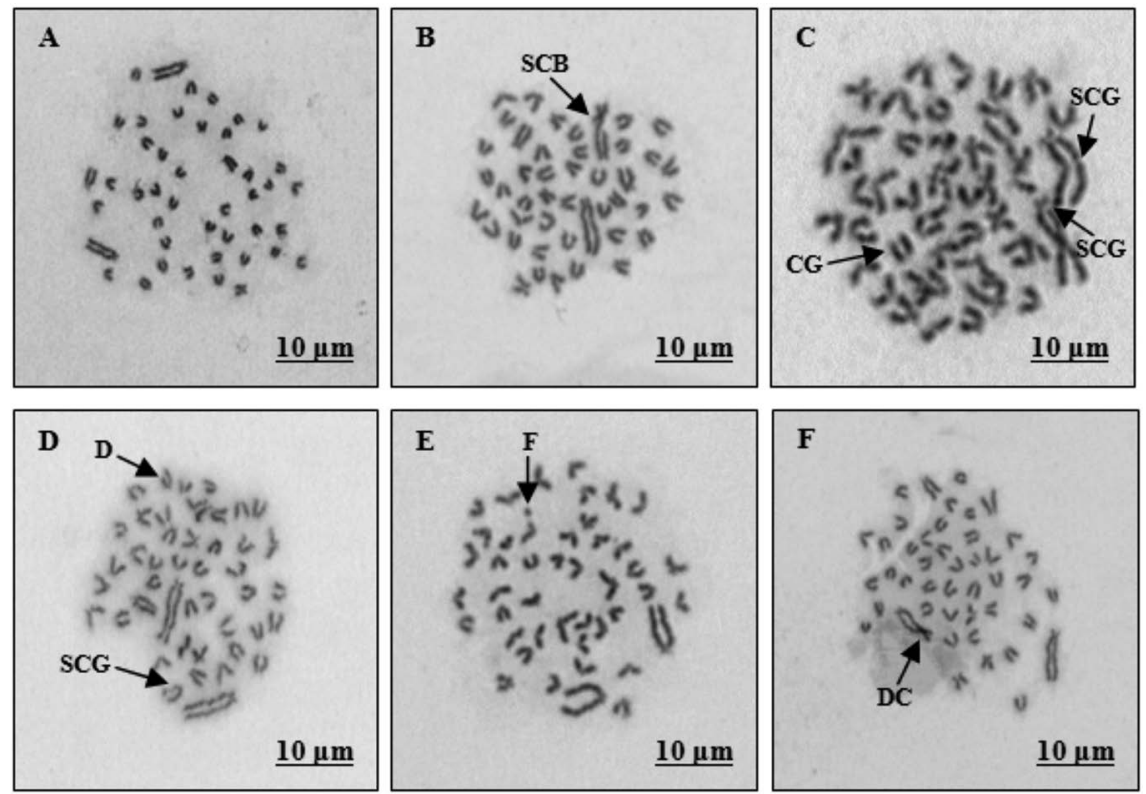

Fig. 5. Different types of chromosomal aberrations in the metaphase spread cells of $O$. niloticus $(2 n=44)$, showing a single chromatid break (SCB), single chromatid gap (SCG), centromere gap (CG), deletion (D), fragmentation (F) and dicentric chromosome (DC) (A: reference site, B-F: domestic wastewater canal).

mestic wastewater canal and reference site were 157 and 17 , respectively.

In addition, the number of cells with chromosomal aberrations in the $O$. niloticus samples from the domestic wastewater canal and reference site was 87 and 14 cells, respectively. The average percentage of chromosomal aberrations in the $O$. niloticus cells from the canal and reference site were 87 and $14 \%$, respectively. Statistical analysis indicates that there are significant differences in the numbers of chromosomal aberrations and the cells with chromosomal aberrations between $O$. niloticus samples from the domestic wastewater canal and refer- ence site $(p=0.024,0.006)$.

Cytogenetic analysis of chromosomes has been employed as a biological dosimeter to estimate the effect of genotoxic agents (pollutants) on fish and is very useful for direct detection of effects in somatic cells (Yunis 1983, Radwan 1996). Chromosomal analysis of $O$. niloticus samples from the domestic wastewater canal and an unaffected reference site indicated that the diploid chromosome numbers are the same, and the NOR location can provide information about the chromosomal evolution. The O. niloticus samples displayed terminal Ag-NOR on chromosome pair 1, which agrees with the 
Table 5. The number and percentage of chromosomal aberrations of $O$. niloticus samples from the domestic wastewater canal and reference site.

\begin{tabular}{|c|c|c|c|c|c|c|c|c|c|}
\hline \multirow{2}{*}{$\begin{array}{l}\text { O. niloticus } \\
\text { samples }\end{array}$} & \multicolumn{6}{|c|}{ Number of chromosomal aberrations } & \multirow{2}{*}{$\begin{array}{c}\text { Total number of } \\
\text { chromosomal } \\
\text { aberrations }\end{array}$} & \multirow{2}{*}{$\begin{array}{c}\text { Number of cells } \\
\text { with chromosomal } \\
\text { aberrations }\end{array}$} & \multirow{2}{*}{$\begin{array}{c}\text { Percentage of } \\
\text { chromosomal } \\
\text { aberrations }\end{array}$} \\
\hline & $\mathrm{SCB}$ & $\mathrm{SCG}$ & $\mathrm{CG}$ & $\mathrm{F}$ & $\mathrm{D}$ & $\mathrm{DC}$ & & & \\
\hline \multicolumn{10}{|c|}{ Domestic wastewater canal } \\
\hline Individual 1 & 10 & 30 & 10 & 4 & 3 & 17 & 64 & 36 & 36 \\
\hline Individual 2 & 5 & 12 & 5 & 1 & 1 & 5 & 29 & 21 & 21 \\
\hline Individual 3 & 5 & 24 & 5 & 1 & 1 & 18 & 54 & 30 & 30 \\
\hline Average/Total & 20 & 66 & 20 & 6 & 5 & 40 & 157 & $87^{\mathrm{a}}$ & $87^{\mathrm{a}}$ \\
\hline \multicolumn{10}{|l|}{ Reference site } \\
\hline Individual 1 & 1 & 4 & 1 & 1 & 0 & 1 & 8 & 7 & 7 \\
\hline Individual 2 & 0 & 2 & 2 & 0 & 0 & 0 & 4 & 4 & 4 \\
\hline Individual 3 & 0 & 2 & 1 & 1 & 0 & 1 & 5 & 3 & 3 \\
\hline Average/Total & 1 & 8 & 4 & 2 & 0 & 2 & 17 & 14 & 14 \\
\hline$P$-value & & & & & & & & $0.024^{\mathrm{a}}$ & $0.006^{\mathrm{a}}$ \\
\hline
\end{tabular}

Remarks: a=significant.

results of Supiwong et al. (2012) who reported that AgNOR was located on the region adjacent to the centromere of chromosome pair 1 . This study provides basic information about $O$. niloticus, and the cytogenetics results can be applied to studies on breeding, conservation and chromosome evolution in $O$. niloticus. The $O$. niloticus samples from the affected and unaffected areas were significantly different in some concentrations of heavy metals and chromosomal aberrations.

Generally, there was a significant difference in the chromosomal aberrations between the domestic wastewater canal and reference site samples. These chromosomal abnormalities may lead to genetic changes in the $O$. niloticus population. Concerns have been expressed about the genetic consequences of pollution to fish populations exposed to low concentrations of heavy metals over prolonged periods (Barker and Rackham 1979). The data from this study indicated that the chromosomal aberration frequency increased with an increase in concentrations of heavy metals (Farag et al. 2009).

The results of this study corresponded to those found by Mohamed et al. (2008), who reported enhancement in the frequency of centromeric attenuation, chromatid break, chromatid gap, deletion, fragmentation, ring chromosome and end to end association in samples exposed to industrial and agricultural wastes. The higher level of chromosomal aberrations in O. niloticus from the affected area may be the result of environmental contamination by domestic wastewater or due to contaminated water with heavy metals and other pollutants such as fertilizers, chemicals and insecticides. Although this study was performed with a small number of $O$. niloticus samples, the detection of chromosomal aberrations suggests that the wastewater canal must be better managed and that the public should consider their management of wastewater discharge.
Conclusion

The water quality of the domestic wastewater canal is suitable for aquatic life. The public should be informed of the results of this study so that they can properly consider the effects of discharging wastewater. Water, sediment and fish obtained from the domestic wastewater canal had concentrations of heavy metals that were lower than the standard limits. $\mathrm{Pb}, \mathrm{Cd}, \mathrm{Cr}, \mathrm{Cu}, \mathrm{Fe}, \mathrm{Mn}$, and $\mathrm{Zn}$ in the water and heavy metals in the sediment of the canal were present at levels below the Thailand standard limits. However, the Ni concentration in individual samples and the average levels exceeded the standard limit in water samples. $\mathrm{Pb}, \mathrm{Cd}, \mathrm{Cu}, \mathrm{Fe}, \mathrm{Mn}, \mathrm{Ni}$ and $\mathrm{Zn}$ levels were below the Thailand standard limits in O. niloticus taken from the domestic wastewater canal, and only the $\mathrm{Cr}$ concentration in $O$. niloticus exceeded the standard, which suggests that fish caught from the domestic wastewater canal can pose health hazards to consumers. The average percentage of chromosomal aberrations of the $O$. niloticus samples from the domestic wastewater canal is higher than the samples from the reference site. The chromosomal abnormalities occurred in fish exposed to water pollution over a long period of time. Exposure to high concentrations of heavy metals is known to cause structural abnormalities of chromosomes, but it does not affect the diploid chromosome number. These fish can endure heavy metal contamination and survive in the contaminated ecosystem.

\section{Acknowledgements}

This study was supported by the Research Group on Toxic Substances in Livestock and Aquatic Animals, ASEA-UNINET Thailand scholarship, Faculty of Science and Integrated Water Resource Management Research and Development Center in Northeast Thailand, 
Khon Kaen University.

\section{References}

Alabaster, J. S. and Lloyd, R. 1980. Water Quality Criteria for Freshwater Fish. European Inland Fisheries Advisory Commission Report (FAO). Butterworth, London and Boston. p. 297.

Amisah, S., Adjei-Boateng, D., Obirikorang, K. A. and Grainie, Q. 2009. Effects of clam size on heavy metal accumulation in whole soft tissues of Galatea paradoxa (Born, 1778) from the Volta estuary, Ghana. Int. J. Fish. Aquac. 1: 14-21.

Ansari, T., Marr, I. and Triq, N. 2004. Heavy metals in environments in marine pollution perspective: A mini review. J. Appl. Sci. (Faisalabad) 4: 1-20.

APHA 2005. Standard Methods for the Examination of Water and Wastewater, 21st edition. American Public Health Association, Washington, D.C.

Arai, R. and Koike, A. 1980. A karyotype study of two species of freshwater fishes transplanted into Japan. Bull. Natl. Mus. Nat. Sci. Ser. B Bot. 7: 87-100.

Barker, G. J. and Rackham, B. D. 1979. The induction of sister-chromatid exchange in cultured fish cells (Ameca splendens) by carcinogenic mutagens. Mutat. Res. 68: 381-387.

Biney, C., Calamari, D., Naeve, H., Maembe, T. W., Nyakageni, B. and Saad, M. A. H. 1987. Scientific bases for pollution control in African inland waters. Chem. Ecol. 3: 49-74.

Boyd, C. E. and Tucker, C. S. 1992. Water Quality and Pond Soil Analysis for Aquaculture. Alabama Agricultural Experiment Station, Auburn University, Auburn. p. 183.

Chand, V. and Prasad, S. 2013. ICP-OES assessment of heavy metal contamination in tropical marine sediments. A comparative study of two digestion techniques. Microchem. J. 111: 53-56.

Chen, T. R. and Chen, H. X. 1983. A comparative study of karyotypes in three tilapia fish. Yi Chuan Xue Bao 10: 56-62.

Chen, T. R. and Ebeling, A. W. 1968. Karyological evidence of female heterogamety in the mosquito fish, Gambisuia affinis. Copeia 1: $70-75$.

Chooseangjaew, S., Tanyaros, S., Maneechot, N., Buasriyot, P., Getlekha, N. and Tanomtong, A. 2017. Chromosomal characteristics of the tropical oyster, Crassostrea belcheri Sowerby, 1871 (Ostreoida, Ostreidae) by conventional and Ag-NOR banding techniques. Cytologia 82: 3-8.

Crosetti, D., Sola, L., Brunner, P. and Cataudella, S. 1998. Cytogenetic characterization of Oreochromis nilotica, O. mossambicus and their hybrid. In: The 2nd International Symposium on Tilapia in Aquaculture, Bangkok. pp. 143-151.

Edwards, J. W., Edyvane, K. S., Boxall, V. A., Hamann, M. and Soole, K. L. 2001. Metal levels in Seston and marine fish flesh near industrial and metropolitan centers in South Australia. Mar. Pollut. Bull. 42: 389-396.

Ellis, L. D. 1996. Chemical and Toxicological Studies on Hazardous Waste Sites in Harris County. Master of Science Thesis, Faculty of Science, Texas Southern University, Houston.

Ellis, M. M. 1937. Detection and measurement of stream pollution. Bulletin of the United States Bureau of Fisheries 48: 365-437.

Farag, M. E., Ramadan, A. A. and Ali, M. A. 2009. Cytogenetic and biochemical effects of whip super herbicide toxicity on Nile tilapia (Oreochromis niloticus). In: The 2nd Global Fisheries and Aquaculture Research Conference, Cairo. pp. 79-95.

Ghazaly, K. S. 1992. Sublethal effects of nickel on carbohydrate metabolism, blood and mineral contents of Tilapia nilotica. Water Air Soil Pollut. 64: 525-532.

Howell, W. M. and Black, D. A. 1980. Controlled silver-staining of nucleolus organizer regions with a protective colloidal developer: A 1-step method. Experientia 36: 1014-1015.
Kasiroek, W., Indananda, C., Luangoon, N., Pinthong, K., Supiwong, W. and Tanomtong, A. 2017. First chromosome analysis of the humpback cardinalfish, Fibramia lateralis (Perciformes, Apogonidae). Cytologia 82: 9-15.

Khangarot, B. S. and Ray, P. K. 1990. Acute toxicity and toxic interaction of chromium and nickel to common guppy Poecilia reticulata (Peters). Bull. Environ. Contam. Toxicol. 44: 832-839.

Liu, C. W., Liang, C. P., Lin, K. H., Jang, C. S., Wang, S. W., Huang, Y. K. and Hsueh, Y. M. 2007. Bioaccumulation of arsenic compounds in aquaculture clams (Meretrix lusoria) and assessment of potential carcinogenic risks to human health by ingestion. Chemosphere 69: 128-134.

Maha Sarakham Administration Office 2012. General Information of Maha Sarakham Province. Maha Sarakham Administration Office, Maha Sarakham.

Mahrous, K. and Abdou, H. 2001. Cytogenetical studies on some Nile fish. Journal of Egyptian German Society of Zoology. Histology. Histochemistry and Genetics 36: 133-144.

Majumdar, K. C. and McAndrew, B. J. 1986. Relative DNA content of somatic nuclei and chromosomal studies in three genera, Tilapia, Sarotherodon, and Oreochromis of the tribe Tilapiini (Pisces, Cichlidae). Genetica 68: 175-188.

Mara, D. 2004. Domestic Wastewater Treatment in Developing Countries. Earthscan, London.

Martins, C., Oliveira, C., Wasko, A. and Wright, M. 2004. Physical mapping of the Nile tilapia (Oreochromis niloticus) genome by fluorescent in situ hybridization of repetitive DNAs to metaphase chromosomes: A review. Aquaculture 231: 37-49.

Martins, C., Wasko, A. P., Oliveira, C., Porto-Foresti, F., PariseMasltempi, P. P., Wright, J. M. and Foresti, F. 2002. Dynamics of $5 \mathrm{~S}$ rDNA in the tilapia (Oreochromis niloticus) genome: Repeat units, inverted sequences, pseudogenes and chromosome loci. Cytogenet. Genome Res. 98: 78-85.

Martins, C., Wasko, A. P., Oliveira, C. and Wright, J. M. 2000. Nucleotide sequence of $5 \mathrm{~S}$ rDNA and localization of the ribosomal RNA genes to metaphase chromosomes of the tilapiine cichlid fish, Oreochromis niloticus. Caryologia 133: 39-46.

Mohamed, M. M., El-Fiky, S. A., Soheir, Y. M. and Abeer, A. I. 2008. Cytogenetic studies on the effect of copper sulfate and lead acetate. Pollution on Oreochromis niloticus fish. J. Cell Biol. 3: $51-60$.

Nakinchar, P. and Sattayarat, Y. 2002. Study of heavy metals in Somthawin Canal and Kudnangyai bed sediments in Mahasarakham Province. Department of Environmental Technology, Faculty of Technology, Mahasarakham University, Maha Sarakham.

Nanda, I., Schatl, M., Feichtinger, W., Schlupp, I., Parzefall, J. and Schmid, M. 1995. Chromosomal evidence for laboratory synthesis of triploid hybrid between the gynogenetic teleost Poecilia Formosa and its host species. J. Fish Biol. 47: 619-623.

National Academy of Sciences (NAS) 1975. Medical and biological effects of environmental pollutants. Nickel. National Research Council, National Academy of Sciences, Washington, D.C. p. 277.

Otchere, F. A. 2003. Heavy metals concentrations and burden in the bivalves (Anadara (Senilia) senilis, Grassostrea tulipa and Perna perna) from lagoons in Ghana: Model to describe mechanism of accumulation/excretion. Afr. J. Biotechnol. 2: 280-287.

Parveen, N. and Shadab, G. G. H. A. 2012. Cytogenetic evaluation of cadmium chloride on Channa punctatus. J. Environ. Biol. 33: 663-666.

Priprem, A., Sripanidkulchai, B., Wirojanagud, W. and Chalorpunrut, P. 2007. Heavy metals in freshwater fish along Pong and Chi Rivers. KKU Res J. 12: 420-430.

Radwan, H. A. 1996. Physiological and genetical changes in some freshwater fishes due to pollution. Master of Veterinary Science Thesis, Faculty of Veterinary Medicine, Zagazig University, 
Zagazig.

Rooney, D. E. 2001. Human Cytogenetics: Constutitional Analysis: A Practical Approach. Oxford University Press, London.

Sangpakdee, W., Phimphan, S., Tengjaroenkul, B., Pinthong, K., Neeratanaphan, L. and Tanomtong, A. 2017. Cytogenetic study of tree microhylid species (Anura, Microhylidae) from Thailand. Cytologia 82: 67-74

Singh, A., Sharma, R. K., Agrawal, M. and Marshall, F. M. 2010. Risk assessment of heavy metal toxicity through contaminated vegetables from wastewater irrigated area of Varanasi, India. Trop. Ecol. 51: 375-387.

Smith, R. G. and Windom, H. L. 1972. Analytical Handbook for the Determination of Arsenic, Cadmium, Cobalt, Copper, Iron, Lead, Manganese, Mercury, Nickel, Silver and Zinc in the Marine and Estuarine Environments. Skidaway Institute of Oceanography, Savannah. pp. 72-76.

Sofy, H. I., Layla, A. M. and Iman, M. K. A. 2008. Karyotypic diversity of some tilapia species. Nature and Science 6: 19-27.

Supiwong, W., Tanomtong, A., Supanuam, P., Seetapan, K., Khakhong, S. and Sanoamuang, L. 2012. Chromosomal characteristic of Nile tilapia (Oreochromis niloticus) from mitotic and meiotic cell division byT-Lymphocyte cell culture. Cytologia 78: 1-6.

Thailand Pollution Control Department (TPCD) 1986. The Standard Levels of Heavy Metals in Tissues of Aquatic Animals. Notification in Ministry of Public Health, No. 98. TPCD, Bangkok.

Thailand Pollution Control Department (TPCD) 1994. Surface Water Quality Standards.Notification of the National Environmental
Board, No. 8. TPCD, Bangkok.

Thailand Pollution Control Department (TPCD) 1995. Domestic Wastewater and Treatment System. Notification in Office of Natural Resource and Environmental Policy and Planning. TPCD, Bangkok.

Thailand Pollution Control Department (TPCD) 2001. Water Quality Standards. Notification in Ministry of Public Health, No. 98. TPCD, Bangkok.

Thailand Pollution Control Department (TPCD) 2004. Soil Quality Standards for Habitat and Agriculture.Notification of the National Environmental Board, No. 25. TPCD, Bangkok.

U.S. Environmental Protection Agency (USEPA) 1986. Ambient aquatic life water quality criteria for nickel. Office of Water, Regulations and Standards, Criteria and Standards Division, United States Environmental Protection Agency, Washington, D. C.

U.S. Environmental Protection Agency (USEPA) 1994. Sample Preparation Procedure for Spectrochemical Determination of Total Recoverable Element, Method 200.2. Environmental Monitoring Systems Lab, Cincinnati.

Vervoort, A. 1980. The karyotypes of seven species of tilapia (Teleostei: Cichlidae). Cytologia 45: 651-656.

World Health Organization (WHO) 1991. Environmental Health Criteria Report No.108. Nickel.WHO, Geneva. p. 383.

Yunis, J. J. 1983. The chromosomal basis of human Neoplasia. Science 221: 227-236. 